\title{
POSTĘPY W PATOGENEZIE, DIAGNOSTYCE I LECZENIU UKŁADOWYCH ZAPALEŃ NACZYŃ ZWIĄZANYCH Z PRZECIWCIALAMI PRZECIWGRANULOCYTARNYMI
}

\section{PROGRESS IN THE PATHOGENESIS, DIAGNOSIS AND TREATMENT OF SYSTEMIC ANCA-ASSOCIATED VASCULITIS}

\author{
Katedra i Klinika Chorób Wewnętrznych, Chorób Tkanki Łącznej i Geriatrii Gdańskiego Uniwersytetu Medycznego \\ ul. Dębinki 7, 80-952 Gdańsk \\ Kierownik: prof. dr hab. n. med. Zbigniew Zdrojewski
}

\begin{abstract}
Summary
Antineutrophil cytoplasmic antibody-associated vasculitis (AAV) is a group of systemic diseases characterized by necrotizing inflammation of small and medium size vessels, without immunologic deposits, and with the presence of specific serum antibodies. Recent genetic and cohort studies should improve the comprehension of the pathogenesis of $\mathrm{AAV}$, the stratification of patients into homogenous groups, and lead to therapeutic implications. Immunosuppressive therapy of AAV includes two major periods: induction of remission and maintenance therapy.

Therapy should be chosen individually, not only depending on the stage and severity of the disease, but also on genetic and some prognostic factors. Previous randomized trials and clinical observations show some possible limitations of treatment with cyclophosphamide and steroids. Rytuximab seems to be a good alternative in those patients in induction therapy as well as in maintenance therapy.
\end{abstract}

K e y w ords: antineutrophil cytoplasmic antibody-associated vasculitis - granulomatosis with polyangiitis - microscopic polyangiitis - individualisation of the treatment.

\section{Streszczenie}

Zapalenia naczyń związane z występowaniem przeciwciał przeciwko cytoplazmie granulocytów (AAV) są grupą układowych chorób charakteryzujących się martwiczym zapaleniem małych i średnich naczyń, skąpym lub brakiem występowania depozytów immunologicznych oraz obecnością krążących przeciwciał. Najnowsze osiągnięcia w badaniach genetycznych i kohortowych powinny znaleźć swoje odbicie w lepszym zrozumieniu etiopatogenezy AAV, dokładniejszej stratyfikacji pacjentów w homogenne grupy, a przede wszystkim osiągnięcia te powinny mieć swoje implikacje terapeutyczne.

Leczenie immunosupresyjne AAV obejmuje dwa okresy indukcję remisji oraz leczenie podtrzymujące. Powinno ono być dostosowane nie tylko do stadium i ciężkości choroby, ale również do uwarunkowań genetycznych i czynników decydujących o rokowaniu. Dotychczasowe badania randomizowane i obserwacje kliniczne wskazują na konieczność ograniczenia stosowania cyklofosfamidu i glikokortykosteroidów oraz częstszego stosowania rytuksymabu zarówno w leczeniu indukcyjnym, jak i podtrzymującym.

H a s $\nmid$ a: zapalenia naczyń związane z przeciwciałami ANCA - ziarniniakowatość z zapaleniem naczyń - mikroskopowe zapalenie naczyń - indywidualizacja leczenia.

Zapalenia naczyń związane z występowaniem przeciwciał przeciwko cytoplazmie granulocytów (antineutrophil cytoplasmic antibody - ANCA) są grupą układowych chorób charakteryzujących się martwiczym zapaleniem małych i średnich naczyń, skąpym lub brakiem występowania depozytów immunologicznych oraz obecnością krążących przeciwciał. Nowa definicja zapaleń naczyń związanych 
z występowaniem ANCA (ANCA associated vasculitis AAV) została przyjęta na konferencji w Chapel Hill w 2012 r. (Chapel Hill Consensus Conference - CHCC) [1].

Zapalenia AAV obejmują mikroskopowe zapalenie naczyń (microscopic polyangiitis - MPA), ziarniniakowatość z zapaleniem naczyń (granulomatosis with polyangiitis GPA), eozynofilową ziarniniakowatość z zapaleniem naczyń (eosinophilic granulomatosis with polyangiitis - EGPA).

Definicje CHCC oparte są na manifestacji klinicznej i histologicznej chorób, nie biorą jednak pod uwagę badań genetycznych i analizy wielkich badań typu ,cluster" (cluster analysis). Mahr $i$ wsp. analizując materiał z 5 badań klinicznych (673 świeżo zdiagnozowanych pacjentów z GPA i MPA), wyróżnili nowe podgrupy AAV związane z przeciwciałami przeciwko myeloperoksydazie (MPO) i proteinazie 3 (PR3), tj. MPO-ANCA zapalenia naczyń i PR3-ANCA zapalenia naczyń (prefix określa rodzaj przeciwciał ANCA) [2]. Badania genetyczne prowadzone przez Lyons A. i wsp. wykazały odmienne podłoże genetyczne układowych zapaleń naczyń, zależnie od rodzaju występujących przeciwciał; MPO-ANCA (pANCA) vs PR3-ANCA (cANCA). W zapaleniach z przeciwciałami PR3-ANCA predyspozycja genetyczna obejmuje właściwości odpowiedzi immunologicznej (locus HLA DP), cechy antygenu (proteinaza 3) i inhibitora jego aktywności (antytrypsyny alfa 1). W zapaleniach naczyń z przeciwciałami MPO-ANCA uwarunkowanie genetyczne dotyczy polimorfizmu w locus DQ układu HLA [3]. Oprócz dobrze znanych przeciwciał anty-PR3 i anty-MPO, w patogenezie AAV biorą udział prawdopodobnie również inne przeciwciała. Dlatego też AAV mogą występować bez obecności ANCA, a ponadto stwierdzono, że aktywność choroby nie koreluje z poziomem ANCA. W patogenezie AAV bierze się pod uwage występowanie takich przeciwciał, jak: przeciwciała hLAMP-2 (antihuman lysosome-associated membrane protein-2), przeciwciała przeciwko moezynie (anti-moesin antibody), przeciwko plazminogenowi i aktywatorowi plazminogenu. Ważną rolę w patogenezie układowych zapaleń naczyń odgrywają również czynniki środowiskowe: zanieczyszczenia środowiska (np. krzem), infekcje (np. gronkowce, E. coli), leki (propyltiouracyl, kokaina). Nie bez znaczenia jest dysregulacja układu immunologicznego, układu dopełniacza, zaburzenia apoptozy i unikalnej formy śmierci neutrofili w mechanizmie NETs (neutrophil extracellular traps) [4].

Najnowsze osiągnięcia w badaniach genetycznych i kohortowych powinny znaleźć swoje odbicie w lepszym zrozumieniu etiopatogenezy AAV, dokładniejszej stratyfikacji pacjentów w homogenne grupy, a przede wszystkim osiągnięcia te powinny mieć swoje implikacje terapeutyczne. Dotychczasowe badania kliniczne wskazują na szereg elementów, które decydują o przeżyciu pacjentów i nawrotach choroby. Należy do nich: rozległość zmian wielonarządowych i ich ciężkość. Przeżycie pacjentów z GPA jest dłuższe niż chorych z MPA, mimo że do nawrotów choroby dochodzi wcześniej i częściej u chorych z GPA [2]. Najgorzej co do przeżycia rokują pacjenci z zajęciem przewodu pokarmowego i układu sercowo-naczyniowego, a ponadto niekorzystnie rokującym czynnikiem jest zajęcie nerek. Im cięższe uszkodzenie nerek (klasa zmian ocenianych w bioptacie nerki, stężenie kreatyniny w surowicy), tym gorsze rokowanie [5]. De Joode $i$ wsp. wykazali, że pacjenci z uszkodzeniem nerek w przebiegu AAV, wymagający leczenia nerkozastępczego, wykazywali gorsze prawdopodobieństwo przeżycia aniżeli chorzy bez zajęcia nerek (HR 0,55; p =0,02). Mniej szans na poprawę lub powrót funkcji nerek mieli chorzy z przeciwciałami przeciwko mieloperoksydazie (MPO-ANCA) w porównaniu z chorymi wykazującymi obecność przeciwciał przeciwko proteinazie 3 (PR3-ANCA) [5]. Podobne obserwacje poczynili Mahr $i$ wsp. [2]. Ponadto, większe szanse na tzw. przeżycie nerkowe mieli pacjenci niewymagający dializy w 6. miesiącu choroby, wykazujący znaczną poprawę funkcji nerek w ostrym okresie choroby i bez nawrotów w przebiegu choroby [5].

Jak już wspomniano, zajęcie nerek jest ważnym predyktorem wzrostu ryzyka śmiertelności i chorobowości w AAV, dlatego też biopsja nerki jest koniecznym elementem diagnostyki choroby nerek i prognozowania w AAV. W zależności od liczby kłębuszków prawidłowych, kłębuszków charakteryzujących się występowaniem półksiężyców komórkowych i kłębuszków szkliwiejących, wyróżnia się 4 klasy kłębuszkowych zapaleń nerek związanych z ANCA (ANCA-associated glomerulonephritis): klasę ogniskową (focal), klasę z półksiężycami (crescentic), mieszaną (mixed) i szkliwiejącą (sclerotic) [6].

Klasa ogniskowa wykazuje dobrą prezerwację funkcji nerek; występowanie półksiężyców komórkowych daje szansę ,wyzdrowienia” nerek, natomiast postać mieszana i sklerotyczna świadczą o umiarkowanym lub dużym ryzyku progresji do krańcowej niewydolności nerek. Oprócz tego naciek limfocytów T w komórkach cewek nerkowych (T-cell tubulitis) jest niezależnym predyktorem spadku filtracji kłębuszkowej [7].

Obecnie zasady leczenia AAV zostały zoptymalizowane na podstawie szeregu badań randomizowanych wykonanych w ciągu ostatnich 20 lat i dostosowane są do stadium oraz ciężkości choroby (ryc. 1). Niestety, nie uwzględniają one odmienności w uwarunkowaniach genetycznych GPA i MPA.

Leczenie immunosupresyjne obejmuje dwa okresy: indukcję remisji trwającą 3-6 miesięcy oraz leczenie podtrzymujące przez co najmniej 18-24 miesiące. Opornością na indukcję remisji układowego zapalenia naczyń określa się brak istotnej poprawy po 4-6 tyg. leczenia immunosupresyjnego.

Do indukcji remisji AAV stosowane są wlewy cyklofosfamidu - CYP (15 mg/kg m.c.) co 2 tyg., następnie co 3 tyg. oraz wysokie dawki glikokortykosteroidów (GKS). Przy indukowaniu remisji wlewami CYP należy zmniejszyć dawkę leku odpowiednio do wieku chorego (> 60. r.ż. $12,5 \mathrm{mg} / \mathrm{kg}$ m.c.; > 70. r.ż. $10 \mathrm{mg} / \mathrm{kg}$ m.c.) i stopnia ubytku filtracji kłębuszkowej.

W trwającym ponad 4 lata badaniu CYCLOPS porównywano wyniki terapii doustnej (2 mg/kg m.c.) i dożylnej 

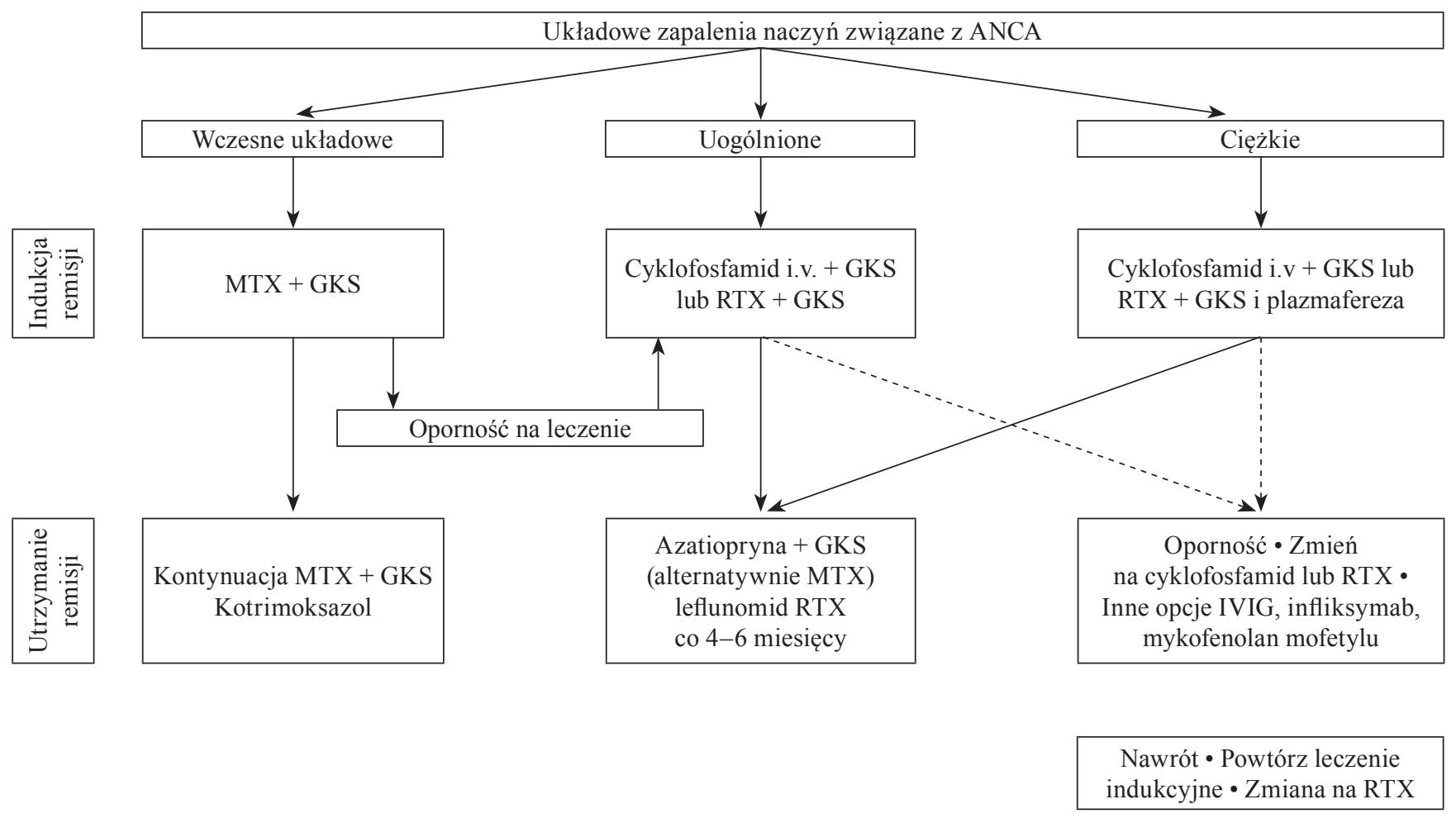

ANCA - przeciwciała przeciwgranulocytarne, GKS - glikokortykosteroidy, MTX - metotreksat, RTX - rytuksymab

Ryc. 1. Schemat leczenia układowych zapaleń naczyń związanych z przeciwciałami przeciwgranulocytarnymi (AAV)

CYP. Terapia dożylna prowadzona była z 50\% obniżką dawki kumulacyjnej leku w stosunku do terapii doustnej. Pacjenci otrzymujący wlewy CYP wykazywali większe ryzyko wznowy choroby. Nie zaobserwowano jednak różnicy w przeżyciu pacjentów i długoterminowej chorobowości [8]. Obecnie dąży się, aby dawki kumulacyjne CYP były jak najmniejsze. Obiecującym sposobem indukcji remisji jest łączenie wlewów rytuksymabu (RTX) z wlewami CYP w obniżonych dawkach, z jednoczesną redukcją dawek prednizonu [9]. Alternatywnie we wczesnych etapach choroby, bez zajęcia nerek, w leczeniu indukcyjnym można stosować metotreksat (MTX) w dawkach 15-25 mg/tydz. doustnie lub podskórnie. W badaniu NORAM nie wykazano różnic w przeżyciu pacjentów i występowaniu objawów ubocznych pomiędzy grupami chorych stosujących w indukcji MTX lub CYP [10]. Czas do nawrotu choroby był krótszy w grupie chorych leczonych MTX, stąd podawano im wyższe dawki GKS.

Niektóre wyniki badań wykazały przydatność mykofenolanu mofetylu (MMF) w leczeniu indukcyjnym AAV [11]. Prowadzone obecnie badanie MYCYC (MMF 2-3 g/dobę vs pulsy CYP $15 \mathrm{mg} / \mathrm{kg}$ ) wstępnie wykazało porównywalny odsetek remisji w 6 . miesiącu leczenia i porównywalny czas do pierwszego nawrotu choroby.

Stosowane leczenie indukcyjne jest efektywne w 80-90\%. Indukująca remisję immunosupresja nie może być jednakże nadmierna, gdyż główną przyczyną śmiertelności w okresie leczenia indukcyjnego są powikłania infekcyjne. Stąd obecnie preferowane jest pulsacyjne podawanie
CYP (niższa dawka kumulacyjna), natomiast odchodzi się od podawania tego leku doustnie. European Vasculitis Society (EUVAS) zaleca również szybką redukcję dawki GKS do 10 mg w 6. miesiącu terapii.

Wielkie nadzieje wiąże się ze stosowaniem RTX w leczeniu indukcyjnym AAV. Dotyczy to szczególnie postaci opornych i sytuacji nawrotu choroby. Uzasadnione jest to, gdyż komórki B odgrywają centralną rolę w patogenezie AAV. Przeciwciała anty-CD20 wywołują deplecję krążących i osiadłych w tkankach limfocytów B przez bezpośrednią ich apoptozę, cytotoksyczność zależną od dopełniacza oraz cytotoksyczność zależną od przeciwciał. W konsekwencji zaburzona jest produkcja przeciwciał ANCA - prozapalnych cytokin, prezentacja antygenu limfocytów T i aktywacja leukocytów [12].

Pierwsze zastosowania RTX pacjentów z AAV dotyczyły postaci choroby opornej na leczenie CYP lub postaci nawrotowej. Lek podawano w dawce $375 \mathrm{mg} / \mathrm{m}^{2} /$ tydz. przez 4 tyg. lub w dawkach po $1000 \mathrm{mg}$ co 2 tyg. Remisję całkowitą lub częściową uzyskano u $62-90 \%$ chorych. Nawroty po zastosowaniu RTX z sukcesem odpowiadały na dalsze leczenie przeciwciałami monoklonalnymi anty-CD20 [12].

Dwie randomizowane próby kliniczne RAVE $[13,14]$ oraz RITUXVAS [15] definitywnie potwierdziły równoważną efektywność RTX i CYP w leczeniu indukcyjnym AAV. Do badania RITUXVAS zakwalifikowano 44 pacjentów ze świeżo wykrytą chorobą. Chorzy otrzymywali RTX $\left(4 \times 375 \mathrm{mg} / \mathrm{m}^{2}\right)$ i 2 pulsy CYP $(15 \mathrm{mg} / \mathrm{kg}$ m.c.) lub pulsy CYP (15 mg/kg m.c.) z następową terapią podtrzymującą 
azatiopryną - AZA (2 mg/kg m.c.) [15]. W badaniu RAVE wzięło udział 198 chorych ze świeżo rozpoznaną chorobą lub po jej nawrocie (GPA lub MPA). Grupa I otrzymała RTX $\left(4 \times 375 \mathrm{mg} / \mathrm{m}^{2}\right)$ oraz GKS w dawkach zmniejszających się do 6. miesiąca leczenia, natomiast grupa II - CYP doustnie (2 mg/kg/dobę) przez 3-6 miesięcy, następnie AZA przez 12-15 miesięcy oraz GKS [13]. W obydwu badaniach dopuszczalne było podawanie na wstępie terapii 1-3 g metyloprednizolonu, następnie prednizonu w dawce $1 \mathrm{mg} / \mathrm{kg}$. Różnica dotyczyła obniżania dawki GKS. W badaniu RITUXVAS w 6 . miesiącu wynosiła ona $5 \mathrm{mg}$ i kontynuowano podawanie prednizonu do 12. miesiąca, natomiast w badaniu RAVE prednizon odstawiono w 5. miesiącu. Odpowiedź na leczenie oceniano w 12. miesiącu w badaniu RITUXVAS i w 6 ., 12., 18. miesiącu w badaniu RAVE. Obydwa badania wykazały jednakową efektywność schematów leczenia opartych na RTX i CYP w świeżo wykrytym AAV. Ponadto badanie RAVE wykazało wyższy wskaźnik remisji w podgrupie nawrotowej po zastosowaniu RTX (67\% vs 42\%, 49\% vs $24 \%, 37 \%$ vs 20\%) [14]. Nie stwierdzono istotnych różnic w częstości występowania poważnych objawów ubocznych w porównywalnych schematach immunosupresji. W badaniu RAVE w grupie RTX rzadziej występowała leukopenia i zapalenie płuc. Zauważyć jednak należy, że w obydwu randomizowanych badaniach w grupie RTX wyeliminowano lub ograniczono stosowanie CYP oraz wprowadzono wczesną redukcję GKS. Tymczasem GKS uznawane są za główny składnik toksyczności terapii AAV. Niektórzy badacze uważają jednak, że wczesne odstawienie GKS skutkuje wzrostem nawrotów choroby [16]. Analiza badania RAVE-IT dokonana przez Specks $i$ wsp., wykazuje, że pacjenci leczeni RTX przez rok nie otrzymywali immunosupresji, a remisja choroby utrzymywała się przez 18 miesięcy [15]. Jest więc nadzieja, że możliwość częstszego stosowania RTX pozwoli bezpiecznie ograniczyć dawkę stosowanych GKS.

W najcięższych postaciach układowych zapaleń naczyń, przebiegających z krwawieniami do pęcherzyków płucnych i/lub głębokim ubytkiem filtracji kłębuszkowej, prowadzone są zabiegi plazmaferezy.

Randamizowane badanie MEPEX, porównujące adjuwantową terapię w ciężkich postaciach AAV z zajęciem nerek (7 plazmaferez w ciągu 14 dni vs 1000 mg metylprednizonu/miesiąc przez 3 miesiące) nie wykazało korzystnych efektów plazmaferez na przeżycie pacjentów, natomiast sugerowało ochronne działanie na funkcję nerek. Plazmaferezy zmniejszały zależność od dializ w 3. miesiącu leczenia, redukowały o $24 \%$ ryzyko rozwoju krańcowej niewydolności nerek w 12. miesiącu oraz zmniejszały liczbę powikłań w czasie leczenia indukcyjnego [17]. Obserwację badanej grupy przedłużono do ponad 4 lat. Walsh $i$ wsp. dokonali analizy, która potwierdziła korzystny wpływ plazmaferez na prewencję rozwoju krańcowej niewydolności nerek (HR 0,64). Ryzyko zgonu z każdej przyczyny nie wykazywało związku z zastosowanym leczeniem (HR 1,08) [18].

Pepper $i$ wsp. porównali podawanie dożylne i doustne CYP u chorych z AAV wymagających dializy i plazma- ferezy [19]. Sposób podawania nie miał wpływu na funkcję nerek wyrażoną eGER w 3. i 12. miesiącu leczenia, natomiast przeżycie pacjentów po 2 latach obserwacji było istotnie dłuższe $\mathrm{w}$ grupie chorych otrzymujących CYP we wlewach dożylnych (Log rang test $p=0,02)$. Dożylne zastosowanie CYP z GKS oraz plazmaferezami może być efektywnym sposobem leczenia ciężkich AAV z zajęciem nerek. Nadal jednak istnieje wiele niejasności co do sposobu leczenia najcięższych chorych na AAV. Wątpliwości dotyczące właściwej dawki GKS i wykonywania zabiegów plazmaferezy ma rozstrzygnąć toczące się randomizowane, wieloośrodkowe badanie kliniczne PEXIVAS obejmujące $>500$ chorych otrzymujących w indukcji RTX lub CYP [20].

W oparciu o kilka badań randomizowanych, ustalono zasady leczenia podtrzymującego AAV, które trwa co najmniej 18-24 miesiące. Stosowane są małe dawki GKS, AZA lub MTX. Badanie CYCAZAREM [21] nie wykazało różnic w nawrotach choroby, gdy stosowano AZA (2 mg/kg m.c.) lub CYP doustnie (1,5 mg/kg m.c.). Oczywiście kumulacyjna dawka CYP obejmująca indukcję i leczenie podtrzymujące w tej drugiej grupie była wyższa. U chorych z zajęciem nerek AZA powinna być głównym lekiem stosowanym w leczeniu podtrzymującym. W innych postaciach choroby lekiem równoważnym z AZA jest MTX. Bezpieczeństwo i efektywność tego leku $(0,3 \mathrm{mg} / \mathrm{kg} / \mathrm{tydz}$.) w prewencji nawrotów choroby potwierdziło badanie WEGENT [22]. Metotreksat jest zalecany przez EUVAS jako lek podtrzymujący dla pacjentów z prawidłową lub nieznacznie upośledzoną czynnością nerek (stężenie kreatyniny w surowicy $<1,5 \mathrm{mg} / \mathrm{dL}$ ) w dawce $20-25 \mathrm{mg} / \mathrm{tydz}$. Zalecana jest suplementacja kwasu foliowego i profilaktyka zakażenia Pneumocystis jiroveci (Kotrimoksazol 960 mg 3 razy w tyg.). Konieczne jest monitorowanie morfologii krwi, czynności nerek i stężenia aminotransferaz.

Wśród opcji terapeutycznych wymienia się również leflunomid. W badaniu porównawczym z MTX (badanie LEM), w leczeniu podtrzymującym GPA stwierdzono większą skuteczność leflunomidu (30 mg/dobę) w zapobieganiu nawrotom choroby, jednak osiągnięto to kosztem wyższego ryzyka poważnych działań niepożądanych. Tak więc pozycja leflunomidu w leczeniu podtrzymującym GPA nadal pozostaje niejasna [23]. U osób źle tolerujących AZA można stosować MMF w dawce $2 \mathrm{~g}$ /dobę. Wprawdzie badanie IMPROVE (MMF 2,0/dobę vs AZA 2 mg/kg m.c.) wykazało wyższe ryzyko nawrotu choroby i krótszy czas trwania remisji w grupie chorych otrzymujących ten lek, to jednak MMF pozostaje opcją terapeutyczną dla określonej grupy pacjentów. Nie powinien on jednak być stosowany jako lek pierwszego wyboru w leczeniu podtrzymującym remisję [24]. Kotrimoksazol w leczeniu podtrzymującym nie powinien być stosowany w monoterapii. Można rozważyć jego stosowanie z innym lekiem immunosupresyjnym, szczególnie w postaciach choroby zajmujących górne drogi oddechowe oraz w celu profilaktyki zakażeń Pneumocystis jiroveci.

Pomimo stosowania leczenia podtrzymującego $10 \%$ pacjentów co roku wykazuje objawy nawrotu choroby. 
Wysoka nawrotowość - sięgająca $60 \%$ przypadków w okresie 5 lat - jest obserwowana przy obecności przeciwciał PR3-ANCA. Leczenie indukcyjne kolejnych nawrotów choroby związane jest $\mathrm{z}$ wczesna i późną toksycznością oraz wzrostem ryzyka śmiertelności i uszkodzenia ważnych życiowo organów.

Obiecującym sposobem podtrzymywania remisji są wlewy RTX co 6 miesięcy. Smith $i$ wsp. opublikowali retrospektywne badanie, w którym po uzyskaniu remisji choroby przez podanie $1 \mathrm{~g}$ RTX z małymi dawkami prednizonu (0-40 mg; średnio $10 \mathrm{mg}$ ) co 2 tyg., podawano rutynowo $1 \mathrm{~g}$ RTX co 6 miesięcy przez 2 lata, zmniejszając dawkę prednizonu do 2,75 mg. Remisję całkowitą lub częściową uzyskano w 6 . miesiącu w 96\%, nawrót choroby po 2 latach w $12 \%$, a po 44 miesiącach w $26 \%$. Tymczasem w grupie, która otrzymała tylko indukcję $2 \times 1,0$ RTX, nawrót choroby po 2 latach wystąpił u $73 \%$, a po 44 miesiącach w $85 \%$ [25]. Wydaje się więc, że 2-letni ustalony schemat podawania RTX zapewnia niski procent nawrotów choroby. Możliwa jest redukacja GKS lub odstawienie immunosupresji. Wobec braku biomarkerów zapowiadających nawrót choroby, rutynowe podawanie RTX jest efektywną strategią do utrzymania remisji.

Godny polecenia jest również protokół zaproponowany przez Mansfielda $i$ wsp. [9], który jest oparty na RTX, niskich dawkach CYP oraz prednizonu. Pozwala on na szybką remisję choroby i długotrwałe jej utrzymanie oraz zmniejszenie objawów ubocznych. Po średnio 156 tyg. obserwacji nawrót choroby wystąpił jedynie u 3 na 23 (13\%) chorych.

Wprowadzenie nowych, skuteczniejszych i bezpieczniejszych terapii skutkuje poprawą rokowania w układowych zapaleniach naczyń związanych z przeciwciałami ANCA. Długoterminowe badanie prowadzone przez EUVAS, obejmujące grupę 535 pacjentów z AAV (średni czas obserwacji 5,2 lat), raportuje kumulacyjny wskaźnik przeżycia rocznego i 5-letniego; odpowiednio 88\% i 78\%. Najczęstszą przyczyną zgonu w pierwszym roku były: infekcje (48\%) i aktywna choroba podstawowa (19\%), natomiast w latach następnych: choroby sercowo-naczyniowe (26\%), nowotwory (22\%) i infekcje (20\%) [26]. W tej samej kohorcie nawrót choroby wystąpił u $38 \%$ pacjentów, częściej w grupie chorych z przeciwciałami PR3-ANCA [27]. Wysokie ryzyko powikłań sercowo-naczyniowych wiązało się z obecnością przeciwciał przeciwko mieloperoksydazie (MPO-ANCA) lub brakiem ANCA. Pozytywną obserwacją było niskie ryzyko występowania nowotworów. Jedynie ryzyko nowotworów skóry (poza czerniakiem) było większe w porównaniu z poprzednimi doniesieniami. Niewątpliwie można to wiązać ze stosowaniem niższych dawek kumulacyjnych CYP i zamianą drogi podawania $\mathrm{z}$ doustnej na dożylną.

Podsumowując, należy stwierdzić, że leczenie zapaleń naczyń związanych z przeciwciałami przeciwgranulocytarnymi powinno być dostosowane do stadium choroby, rozległości zmian narządowych i ich ciężkości. W leczeniu indukcyjnym trwającym 3-6 miesięcy należy stosować wlewy CYP i/lub RTX, w wybranych przypadkach korzystne jest stosowanie MMF. W najcięższych postaciach zalecana jest plazmafereza. Ponadto należy ograniczyć stosowanie GKS. W leczeniu podtrzymującym zasadnicze znaczenie ma AZA, MTX z małymi dawkami GKS lub bez tych leków. Obiecującym sposobem podtrzymywania remisji są rutynowe wlewy RTX. Inne opcje terapeutyczne wymagają dalszych badań w celu określenia ich efektywności i bezpieczeństwa.

\section{Piśmiennictwo}

1. Jannette J., Falk R., Bacon P., Basu N., Cid M.C., Ferrario F. et al.: Revised international Chapel Hill consensus conference nomenclature of vasculitis. Arthritis Rheum. 2012, 65, 1-11.

2. Mahr A., Katsahian S., Vavet H., Gullevin L., Hagen E.Ch., Hoglund P. et al.: Revisiting the classification of clinical phenotypes of antineutrophil cytoplasmic antibody-associated vasculitis: a cluster analysis. Ann Rheum Dis. 2013, 72, 1003-1010.

3. Lyons P.A., Rayner T.F., Trivedi S., Holle J.U., Watts R., Jayne D.R.W. et al.: Genetically distinct subsets within ANCA-associated vasculitis. N Engl J Med. 2012, 367, 214-223.

4. Furuta S., Jayne D.R.W.: Antineutrophil cytoplasm antibody-associated vasculitis: recent developments. Kidney Int. 2013, 84, 244-249.

5. de Jode A.A.E., Sanders J.S.F., Stegeman C.A: Renal survival in proteinase 3 and myeloperoxidase ANCA-associated systemic vasculitis. Clin J Am Soc Nephrol. 2013, 8, 1709-1717.

6. Berden A.E., Ferrario F., Hagen E.C.: Histologic classification of ANCA-associated glomerulonephritis. J Am Soc Nephrol. 2010, 21, 1628-1636.

7. Berden A.E., Jones R.B., Erasmus D.D.: Tubular lessons predict renal outcome in antineutrophilcytoplasmatic antibody-associated glomerulonephritis after rituximab therapy. J Am Soc Nephrol. 2012, 23, 313-321.

8. Harper L., Morgan M.D., Walsh M., Jayne D.R.W., de Groot K., Gregorini $G$. et al.: Pulse versus daily oral cyclophosphamide for induction in ANCA-associated vasculitis: long-term follow-up. Ann Rheum Dis. 2012, 71, 955-960.

9. Mansfield N., Hamour S., Habib A.M., Tarzi R., Levy J., Griffith M. et al.: Prolonged disease - free remission following rituximab and low-dose cyclophosphamide therapy for renal ANCA: associated vasculitis. Nephrol Dial Transplant. 2011, 26, 3280-3286.

10. Faurschon M., Westman K., Rasmussen N.: Long-term outcome of a clinical trial comparing metothrexate to cyclophosphamide for remission induction of early systemic ANCA-associated vasculitis. Arthritis Rheum. 2012, 64, 3472-3477.

11. Zdrojewski $Z$ :: Mycophenolate mofetil for treatment of vasculitis. Forum Nefrol. 2013, 6, 55-62.

12. Alberici F., Jayne D.R.W.: Impact of rituximab trials on the treatment of ANCA-associated vasculitis. Nephrol Dial Transplant. 2013, 1, 1-12.

13. Jones R.B., Tervaret J.W.C., Hauser T., Luqmani R., Morgan M.D., Peh C.A. et al.: Rituximab versus cyclophosphamide in ANCA Associated Renal Vasculitis. N Engl J Med. 2010, 363, 211-220.

14. Stone J.H., Merkel P.A., Spiera R., Seo Ph., Langford C.A., Hoffman G.S. et al.: Rituximab versus cyclophosphamide for ANCA-associated vasculitis. N Engl J Med. 2010, 363, 221-232.

15. Specks U., Merkel P.A., Seo Ph., Spiera R., Langford C.A., Hoffman G.S et al:: Efficacy of Remission - Induction regimens for ANCA-associated vasculitis. N Engl J Med. 2013, 369, 417-427.

16. Walsh M., Merkel P.A. Mahr A., Berden A., Westman K., Stegman C. et al:: Effects of glucocorticoid therapy on relapse rate in antineuthrophil cytoplasmic antibody-associated vasculitis. A meta-analysis. Arthritis Care Res. 2010, 62, 1166-1173.

17. Jayne D.R.W., Gaskin G., Rasmussen N., Rasmussen N., Abramowicz D. Ferrario F. et al.: Randomized trial of plasma exchange or high-dosage 
methylprednisolone as adjunctive therapy for severe renal vasculitis. J Am Soc Nephrol. 2007, 18, 2180-2188.

18. Walsh M., Casian A., Flossmann O., Westman K., Hoglund P., Pusey Ch. et al.: Long-term follow-up of patients with severe ANCA-associated vasculitis comparing plasma exchange to intravenous methylprednisolone, treatment is uncler. Kidney Int. 2013, 84, 397-402.

19. Pepper R.J., Chanouzas D., Tarzi R., Little M.A., Casian A., Walsh M. et al.: Intravenous cyclophosphamide and plasmapheresis in dialysis - dependent ANCA-associated vasculitis. Clin J Am Soc. Nephrol. 2013, 8, 219-2013.

20. Walsh M., Merkel P.A., Peh Ch.A., Szpirt W., Gullevin L., Pusey Ch.D. et al: Plasma exchange and glucocorticoid dosing in the treatment of anti-neutrophil cytoplasm antibody associated vasculitis (PEXIVAS): protocol for randomized controlled trial. http://www.trialsjournal.com/ content/14/1/73.

21. Laurino S., Chandhry A., Booth A.: Prospective study of TNF blockade with adalimumab in antineutrophil cytoplasmic antibody-associated systemic vasculitis with renal involvement. Nephrol Dial Transplant. 2010, 25, 3307-3314.
22. Pagnoux C., Mahr A., Hamidon M.A.: Azathioprine or methotrexate maintenance for ANCA-associated vasculitis. N Engl J Med. 2008, 359, 2790-2803.

23. Metzler C., Miehle N., Maugler K.: Elevated relapse rate under oral methotrexate versus leflunomide for maintenance of remission in Wegener's granulomatosis. Rheumatology. 2007, 46, 1087-1091.

24. Hiemstra T.F., Walsh M., Mahr A., Savage C.O., de Groot K., Harper L. et al:: Mycophenolatemofetil vs azathioprine for remission maintenance in anti-neutrophil cytoplasmic antibody associated vasculitis: a randomized controlled trial. JAMA. 2010, 304, 2381-2388.

25. Smith R.M., Jones R.B., Guerry M.J., Laurino S., Catapano F., Chaudhry A. et al.: Rituximab for remission maintenance in relapsing antineutrophil cytoplasmic antibody-associated vasculitis. Arthritis Rheum. 2012, 64, 3760-3769.

26. Flossmann O., Berden A., de Groot K., Hagen C., Harper L., Heijl C. et al.: Long-term patient survival in ANCA-associated vasculitis. Ann Rheum Dis. 2011, 70, 488-494.

27. Walsh M., Flossmann O., Berden A., Westman K., Hoglund P., Stegeman $C$. et al.: Risk factors for relapse of antineutrophil cytoplasmic antibody-associated vasculitis. Arthritis Rheum. 2012, 64, 542-548. 